\title{
Antimicrobial and physico-chemical effects of essential oils on fermented milk during preservation
}

\author{
Tovidé Sènou Noël${ }^{1}$, Adeoti Kifouli1 ${ }^{\star}$, Yèhouénou Boniface ${ }^{2}$, Dahouénon-Ahoussi Edwige ${ }^{2}$, Baba- \\ Moussa Farid 1 , Toukourou Fatiou ${ }^{1}$ \\ ${ }^{1}$ Laboratoire de Microbiologie et des Technologies Alimentaires, Faculté des Sciences et Techniques/Université \\ d'Abomey-Calavi, Cotonou, Benin \\ 2Laboratoire d'Étude et de Recherche en Chimie Appliquée, EPAC/ UAC. \\ *: corresponding author ; zoulade@yahoo.fr
}

Original submitted in on $3^{\text {rd }}$ February 2016. Published online at www.m.elewa.org on 31st March 2016 http://dx.doi.org/10.4314/jab.v99i1.12

\begin{abstract}
Objectives: Milk and milk products are known to be the good media for development of many microorganisms. Some essential oils are known to have antimicrobial activities against bacteria, mould and fungi. With the aim of contributing to the preservation of the fermented dairy products, the present study explored the use of essential oils for biopreservation in food pathogen control. The objectives were to study the effect of two essential oils extracted from local plants Xylopia aethiopica (Dunal) A.Rich. and Pimenta racemosa (Mill.) J.W. Moore on the physico-chemical, microbiological and organoleptic characteristics of the fermented milk.

Methodology and Results: At the first level, essential oils were extracted from the leaves of plants and the minimum inhibitory concentration (MIC) of each one was detected using the serial dilution method and Muller Hinton Broth medium. The references strains used were Staphylococcus aureus ATCC 25923 and Escherichia coli ATCC 25922. Based on the MICs determined, essential oils were added to fermented milk and determination of its physicochemical characteristic, evolution of the microbial flora (meophilic flora, lactic flora, coliforms, Staphylococcus aureus ) were done during two weeks of preservation. The results showed that Xylopia aethiopica had a lowest minimum inhibitory concentration. After fifteen days of preservation, a decrease of mesophilic flora and lactic bacteria was observed and a disappearance was noticed for coliforms, thermotolerant coliforms and Staphylococcus aureus during the same time. These results prove the efficiency of those essential oils in fermented milk preservation. Moreover, microorganisms' inhibition was more pronounced with Xylopia aethiopica essential oil than the Pimenta racemosa one.

Conclusion and applications of findings: The study results showed a possible way of using essential oils as an alternative to chemical additives used for preservation of food products. As there are natural products, there could take an important part in the food safety policies.
\end{abstract}

Key words: Essential oils, biopreservation, fermented milk

\section{INTRODUCTION}

In Benin, agriculture contributes to $37 \%$ on gross domestic product (GDP) among which livestock stands to $6 \%$ of this part (Alkoiret et al., 2011). The milk produced from this livestock is quantitavely low 
and varies from $1 \mathrm{~L}$ to $2.5 \mathrm{~L}$ per day according to the breeds (Dossou et al., 2006). Indeed, milk is a high nutritious food, which contains lactose, protein, minerals, vitamins, fats and casein (Mahaut et al., 2000; Vierling, 2003). In most of developing countries, local populations in rural areas consume milk fresh. In urban areas it is consumed both fresh and as other milk-derived products in which the most known is yogurt. In Benin, milk mostly produced by pastoral community, plays an important role in their daily food nutrition and contributes up to $50 \%$ of household (Ogodja et al., 1991) income through milk selling or by-products. Besides the low production of milk in Benin, the major problem is related to its preservation. To avoid the problem of preservation, milk is transformed into traditional cheese so called "waragashi" in local language. The milk pH close to neutral and water content around $90 \%$ to $92 \%$ makes it quickly perishable and susceptible to microorganisms attacks such as bacteria, moulds and yeasts. During milk storage, chemical reactions occur due to the presence of microorganisms, which induce deterioration of nutritional and organoleptic qualities and reducing the duration of preservation. Spoilage and contamination may occur in the milk chain because of poor hygiene, long periods of transportation and lack of appropriate storage facilities. Despite its nutritional value, milk also serves as a good medium for the growth of many microorganisms. To avoid the short-term conservation of milk and its by- products, it is important to inhibit or slow down these mechanisms

\section{MATERIAL AND METHODS}

Collection of plant material and extraction of essential oils: The plant material is constituted by the fresh leaves of Xylopia aethiopica and of Pimenta racemosa harvested respectively in Djassin Tokpa (PortoNovo) and in Malawi (Adjarra) in the department of Ouémé. These Fresh leaves were then used for essential oils extraction. The essential oils were extracted from fresh leaves by the method of hydro-distillation in a distiller type Clevenger. Obtained essential oils were dried over anhydrous sodium sulphate and preserved at $4^{\circ} \mathrm{C}$ until their use.

Determination of Minimal Inhibitory Concentration: The method of microdilution using microplates of 96 wells which occurred during milk deterioration. In the fermented products, such as yogurt, maintain vitality of lactic flora is very important. Therefore, different methods and use of natural or chemical antioxidant and preservatives are applied to reach this purpose (Abdenouri et al., 2008) in order to extend the duration of preservation. Also, the limitation imposed by the food industry and the regulatory authorities about the use of certain synthetic food additives led to a renewed interest in the search for alternatives, as natural antimicrobial compounds, in particular those of vegetable origin (Hammer et al., 1999). Essential oils appeared for many years to be an alternative in foods preservation process. Essential oil as well as compound by-products possess important activities of which the most studied is antimicrobial activity. Indeed, the antioxidant, bactericidal and fungicidal activities of essential oil extracted from several plants were studied by several researchers (Rasooli \& Mirmostafa, 2002; Tepe et al., 2005; Giordani et al., 2005 ; Sacchetti et al., 2005 ; Valero \& Frances , 2006). The study aims to explore the use of essential oils in biopreservation of food pathogen control. The objectives are to study the effect of two essential oils extracted from local plants Xylopia aethiopica and Pimenta racemosa on the physico-chemical, microbiological and organoleptic characteristics of the fermented milk. Pimenta racemosa and Xylopia aethiopica are plants that have antimicrobial properties. Both essential oils were reported to have antimicrobial activities on Staphylococcus aureus and Escherichia coli strains.

according to Bajpai et al. (2008a) and reported by Yèhouénou et al. (2010ab) was used. Two (2) $\mathrm{ml}$ of Mueller Hinton Broth (MHB) added by phenol red at the concentration of $0.02 \mathrm{~g} / \mathrm{l}$ were used to dilute $40 \mu \mathrm{l}$ of essential oil. Two (2) drops of Tween 80 were added to facilitate the mixture. The mixture of tested essential oil and Muller-Hinton Broth (MHB) medium was used as a negative control and the positive control was carried out with a mixture of tested microorganism. After making serial dilutions well by well, the microplate was covered and incubated at $37^{\circ} \mathrm{C}+/-1^{\circ} \mathrm{C}$ for twenty four (24) hours. Collection of biological material: The fresh milk was bought early the morning, just after milking in stock farms 
of the city of Abomey-Calavi. Samples were carried cold and stored in the refrigerator before the manipulations.
Figure 1 show the diagram used for production of fermented milk in which essential oil was added.

\section{Fresh Milk}

Distribution into pots

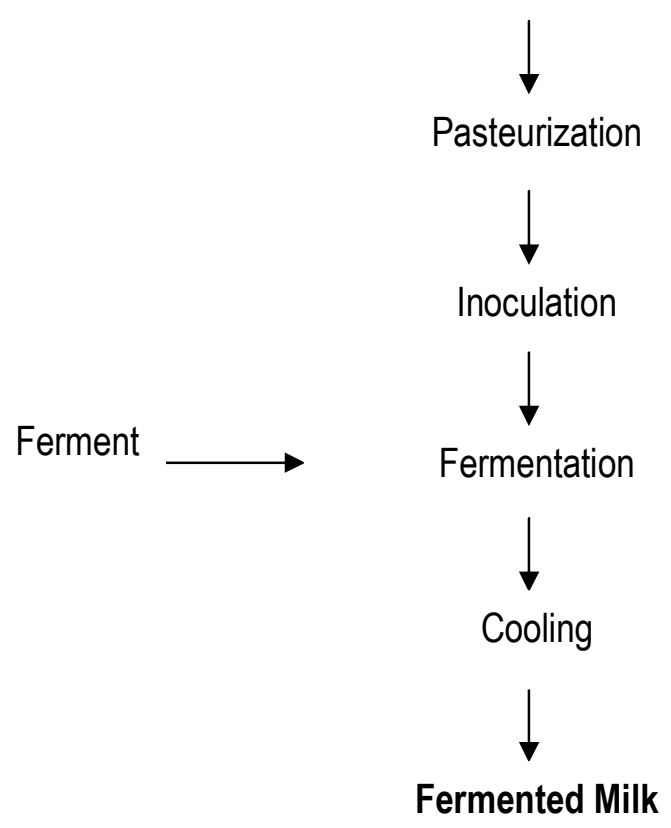

\section{Addition of essential oil $\longrightarrow$ Fermented Milk +essential oïl}

Figure 1: Production of fermented milk containing essential oil

Physico-chemical analysis: Physico-chemical analysis concerned $\mathrm{pH}$ determination and peroxide index. For $\mathrm{pH}$ determination, the $\mathrm{pH}$ of fresh milk, fermented milk and fermented milk added with some essential oil was raised (found) every day during fifteen (15) days of preservation. Peroxide index was measured according to the standard method NT. 118.22 (1996). This value was estimated every three (03) days during the fifteen days of preservation.

Microbiological analysis: Milk samples were analyzed for their microbiological quality. Microbial flora of fresh milk, fermented milk without oil and fermented milk added with each type of essential oil were traced during fifteen (15) days storage at ambient temperature. Finally, the four types of samples were used for microbiological analysis. Fresh milk was used as a control. Enumeration of total mesophile flora using Plate Count Agar (PCA) with plates incubation at $30^{\circ} \mathrm{C}$ had been done for 72 hours. Coliforms were determined using violet red bile lactose agar (VRBL) after 24 hours \pm 2 at $37^{\circ} \mathrm{C}$ and $44^{\circ} \mathrm{C}$. The enumeration of total coliform was determined according to the NF standard method V08-050-199. The Staphylococci are determined according to the standard (ISO 15213-2003) by using the Baird-Parker (BP) 
medium after incubation at $37^{\circ} \mathrm{C}$ for 24 hours. Enumeration of the lactic flora was made on the ManRogosa-Sharpe agar (M.R.S) medium with incubation at $30^{\circ} \mathrm{C}$ during 72 hours. Preparation of decimal dilution of each sample has been done using the maximum recovery diluents.

Data analysis: Data obtained were statistically analyzed using Statistical Package for Social Scientists (SPSS)

\section{RESULTS AND DISCUSSION}

Minimal inhibitory concentration (MIC) of the two essential oils: The MICs of Xylopia aethiopica essential oil (EO) for the two microorganisms are $0.23 \mathrm{mg} / \mathrm{ml}$ and $0.46 \mathrm{mg} / \mathrm{ml}$, while those for Pimenta racemosa are 1.10 $\mathrm{mg} / \mathrm{ml}$ and $0.55 \mathrm{mg} / \mathrm{ml}$ respectively for Staphylococcus aureus and Escherichia coli are (Table 1). MIC values version 17.0. Data were expressed as mean \pm standard deviations of three replicate determinations (Pillai \& Nair, 2013). The data obtained for each sample were evaluated for significant differences in their means with analysis of variance (ANOVA). Critical difference at $p=0.05$ was estimated.

obtained for Xylopia aethiopica near those obtained by Yèhouénou et al. (2010a) for the same microorganisms that were respectively $0.27 \mathrm{mg} / \mathrm{ml}$ and $0.54 \mathrm{mg} / \mathrm{ml}$. the study noted that the tested strains were more sensitive to Xylopia aethiopica essential oil than to Pimenta racemosa.

Table 1: Determination of minimal inhibitory concentration of tested oils

\begin{tabular}{lcc}
\hline Tested strains & \multicolumn{2}{c}{ MIC $(\mathrm{mg} / \mathrm{ml})$} \\
\cline { 2 - 3 } & Pimenta racemosa & Xylopia aethiopica \\
\hline Staphylococcus aureus ATCC 25923 & 1.10 & 0.23 \\
Escherichia coli ATCC 25922 & 0.55 & 0.46 \\
\hline
\end{tabular}

\section{Effect of essential oils on milk flora during storage}

Total mesophilic flora: The aerobic mesophilic flora of fresh milk determined before fermentation was 2,5.105 CFU (Table 2). This value was higher than the standard recommend for fresh milk, which is $5.10^{4}$. During fermentation after 5,10 and 15 days of storage at $4^{\circ} \mathrm{C}$, the value determined were respectively $10^{4}, 3.10^{3}$ and $2.10^{3} \mathrm{CFU} / \mathrm{ml}$. This flora did not exceed the critical threshold of $5.10^{4} \mathrm{CFU} / \mathrm{ml}$ during the fifteen days of preservation. During the period of storage, mesophile flora of fermented milk added with essential oils also decreased significatively (Table 3). The total number of flora estimated were lower than those obtained with fresh milk and fresh milk fermented without oil. Analysis of variance showed a significant difference between fermented milk added with essential oils and which fermented without essential oils. Indeed, fermented milk added with essential oil of Pimenta racemosa and Xylopia aethiopica had respectively $5.10^{2} \mathrm{CFU} / \mathrm{ml}$ and $3,6.10^{2}$ $\mathrm{CFU} / \mathrm{ml}$ after fifteen days of preservation. This result showed the low level of microbial proliferation in which added with Xylopia aethiopica oil than the other.

Table 2: Microbial flora of fresh milk

\begin{tabular}{c|c|c}
\hline & Fresh milk & Standard \\
\hline Mesophile flora & $2,5.10^{5}$ & $5.10^{4}$ \\
Lactic flora & $7.10^{3}$ & - \\
Coliforms & $2,8.10^{2}$ & $10^{2}$ \\
Thermotolerant coliforms & $1,6.10^{3}$ & 1 \\
Staphylococcus aureus & $1,9.10^{3}$ & $10^{2}$ \\
\hline
\end{tabular}

Coliforms: As total aerobic mesophile flora was determined, the coliforms had been enumerated for fresh milk fermented, fermented milk added with essential oils. Table 3 showed the results obtained for each sample during the same period of preservation. The level of coliform decreased with the time of preservation in the three types of sample. Moreover, this decrease is more important in the fermented milk added with essential oils especially with Pimenta racemosa compared to the other. Indeed, enumerated coliform was below the critical threshold, which is the $10^{2} \mathrm{CFU} / \mathrm{ml}$. This result showed that essential oils of these species contributed to the 
reduction of coliforms. In the same line, variation of the rate of the thermo-tolerant coliforms (TTC) in fermented milk preserved with or without essential oil was also determined. The number of unit forming colonies of the TTC decreased, in a fast way during the fifteen days of preservation samples. However, the number of TTC was lower than that required by the standard, which is $1 \mathrm{CFU} /$ $\mathrm{ml}$.

Lactic flora: The lactic flora $(\mathrm{FL})$ of the milk fermented without essential oil after 5,10 and 15 days of preservation in $4^{\circ} \mathrm{C}$ is respectively $10^{7}, 4.10^{6}$ and $10^{6}$
$\mathrm{CFU} / \mathrm{ml}$. During the period of storage, the FL knew a significant decrease for the two (2) lots of fermented milk preserved with essential oils. The fermented milk preserved with Pimenta racemosa oil presented for 5,10 and 15 days respectively a rate of $28.10^{5}, 8.10^{5}$ and $14.10^{4} \mathrm{CFU} / \mathrm{ml}$ and a respective rate of $12.10^{5}, 44.10^{4}$ and $9.10^{4} \mathrm{CFU} / \mathrm{ml}$ for that preserved with Xylopia aethiopica. This flora exceeded the critical threshold of $10^{2} \mathrm{CFU} / \mathrm{ml}$ during the fifteen days of preservation for three lots (Table 3).

Table 3: Enumeration of specific flora of fermented milk with and without essential oils

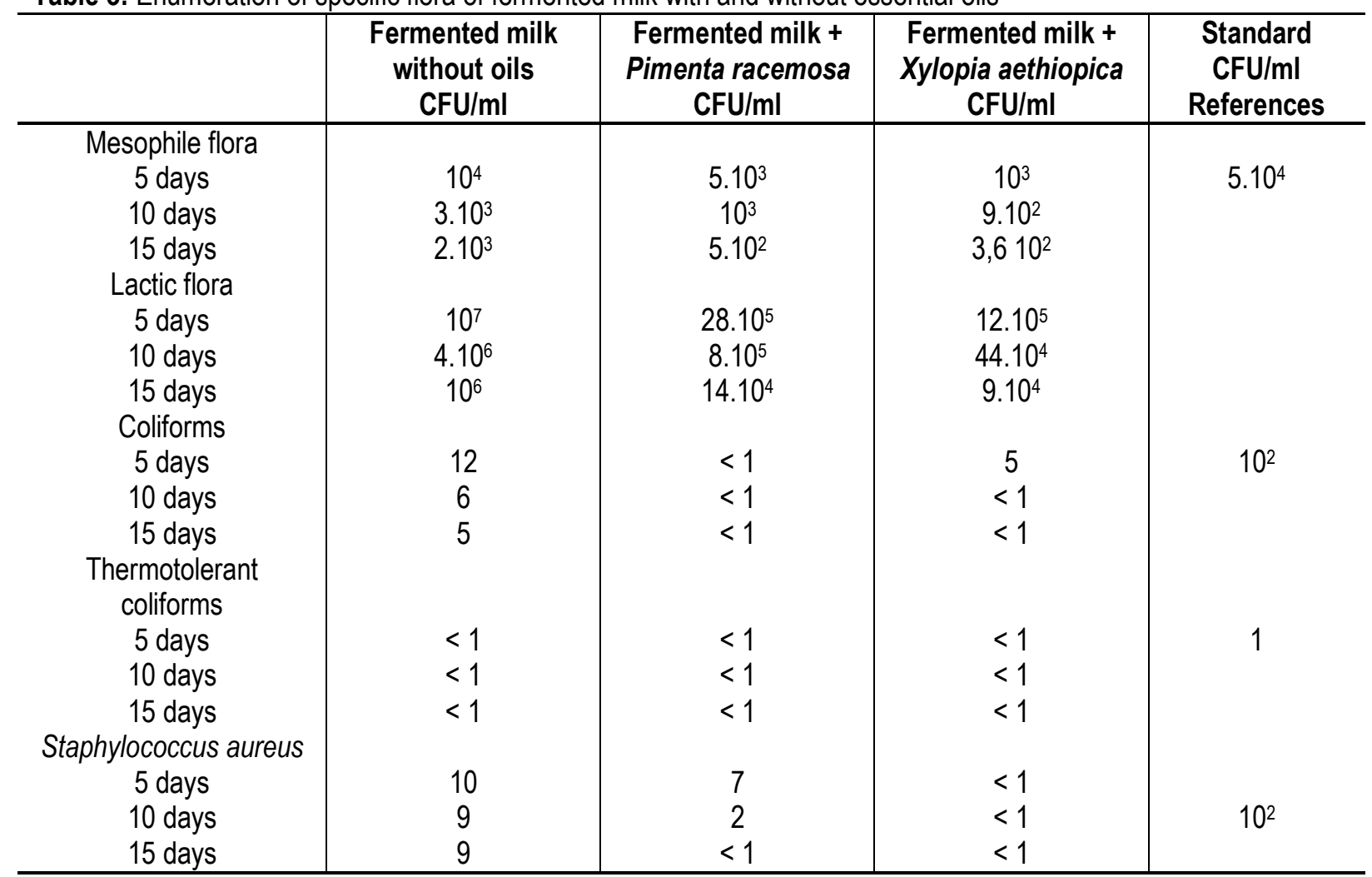

Enumeration of Staphylococcus sp. Flora: The variations of the rate of staphylococci in fermented milk preserved with or without essential oils are enumerated. The number of colonies (CFU/ml) of staphylococci decreases in a fast way in the samples during the fifteen days of preservation. However, the number of staphylococci is lower than that required by the standard, which is $10^{2} \mathrm{CFU} / \mathrm{ml}$ for the three lots.

Influence of essential oils on Physico-chemical characteristics of milk
Evolution of $\mathrm{pH}$ during storage: The values of $\mathrm{pH}$ had been determined during the same period of preservation for all samples. $\mathrm{pH}$ varied from 4.73 to $4.96,4.03$ to 4.16 and 4 to 4.2 respectively for milk fermented without additive, fermented milk preserved with Pimenta racemosa and fermented milk preserved with Xylopia aethiopica (Figure 2). The lowest values of $\mathrm{pH}$ were observed for the milk preserved with essential oils although all $\mathrm{pH}$ values were acids. Nevertheless, analysis of variance showed no difference between values obtained for the completely fermented milk. 


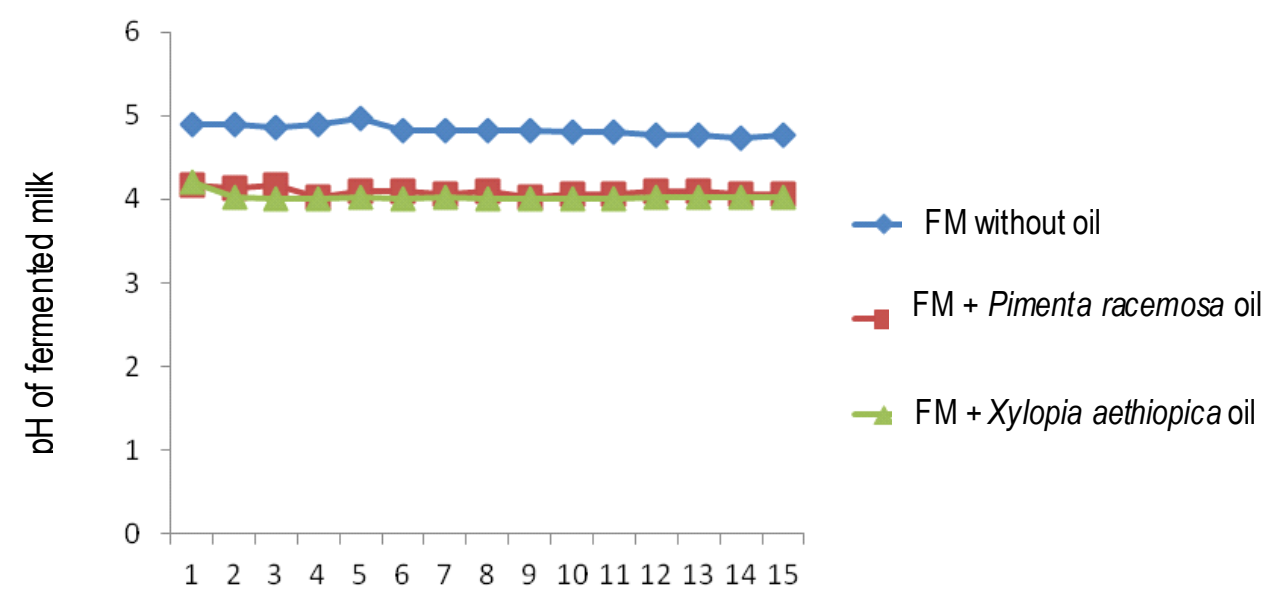

Figure 2: Evolution of $\mathrm{pH}$ in fermented milk during preservation

Evolution of peroxide index: The peroxide index showed an increasing during the first ten (10) days of preservation for all fermented milk apart from addition or not of essential oils. After this, a decrease was observed during the last days resulting in the production on secondary metabolites derived from peroxide decomposition (Figure 3). The consequence is the production of smell rancid and bad taste. Using ANOVA test and application of Duncan' test, a significant difference was observed between fermented milk and which added with essential oils. On the other hand, there was a significant difference between fermented milk preserved with essential oils. Pimenta racemosa' oil has antioxidant activity and contributed to reduce the degree of oxidation of the fat through inhibition of free radical formation (Eymard, 2003). Similar results had been reported for Xylopia aethiopica with a lower effect than those observed with Pimenta racemosa (Asekun \& Adeniyi, 2004; Noudogbessi et al., 2011).

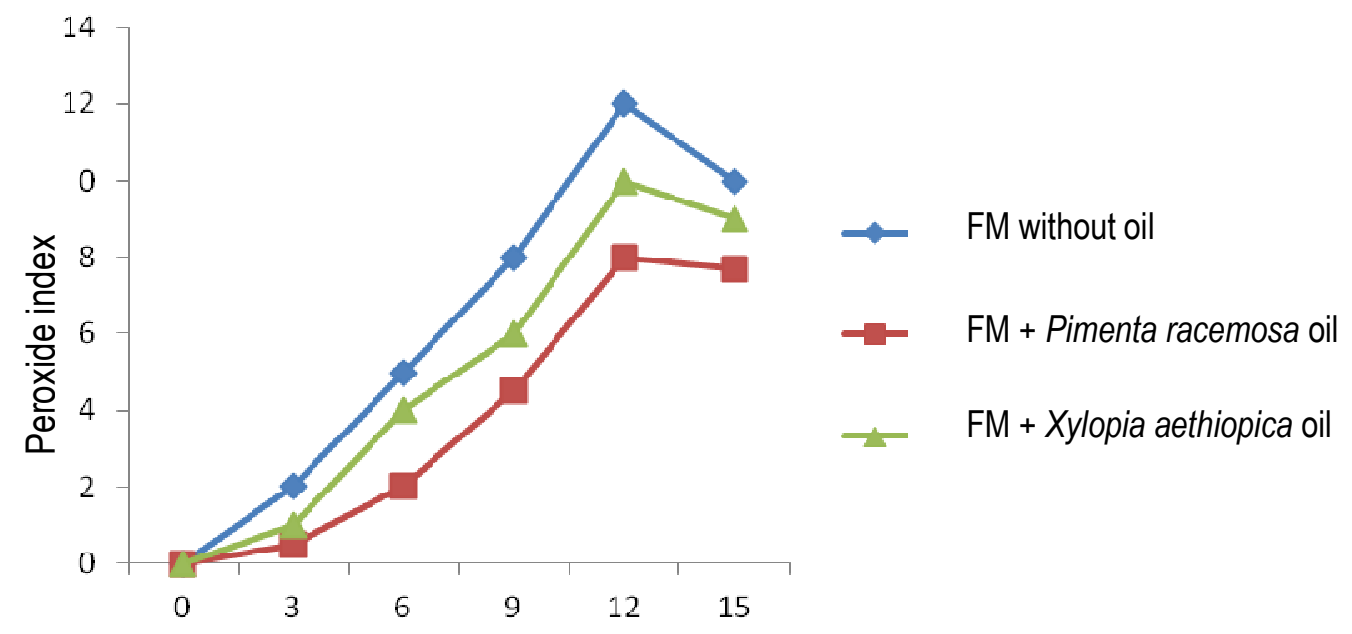

Days of preservation

Figure 3: Evolution of peroxide index of fermented milk fat content during preservation 


\section{DISCUSSION}

The low pH observed for all fermented milk could be explained on the one hand by fermentation due by lactic bacteria and on the second hand by the action of essential oils. Indeed, essential oils had an acid property, which is in relation with the peroxide index. These results were proved by the $\mathrm{pH}$ value obtained with fermented milk added by essential oils were low $\mathrm{pH}$ were obtained. Many studies showed the biological activities of essential oils (Deans \& Ritchie, 1987 ; Bajpai et al., 2008a,b;) and their multiple applications inside foods as antimicrobials (Lambert et al., 2001; Smith et al., 2001; Kèkè et al., 2009; Yèhouénou et al., 2010b). It was observed a decrease of microbial flora such as mesophile germs, coliforms, lactic bacteria and Staphylococci flora species in all fermented milk added with essential oils when compared with the control. The highest value was found in fermented milk without oil, while the lowest was detected in fermented milk obtained with essential oils. Results from the Analysis of Variance (ANOVA) suggested that there was a significant difference $(P<0.05)$ in bacterial loads between the two groups of samples. The use of essential oil of Pimenta racemosa and Xylopia aethiopica in the preservation of the fermented milk allowed us to notice that the efficiency of these oils on the bacterial flora is reduced when it is mixed with milk. The reduction of the microbial activity of oils on the bacteria of the fermented milk could be explained by the reduction of the contact area with the bacteria, which is doubtless function of the rate of miscibility of oil with milk. However, we noticed a real contribution of these oils to the reduction of the bacterial flora of the milk when we compare samples tests with the control without oil. In the fermented milk preserved without oil, we also noticed a decrease of the bacterial flora during the time of preservation except Staphylococcus' flora that remained intact. The persistence of this microbial flora could be explained by an insufficiency of acidity of milk resulted from fermentation and essential oil action to inhibit the

\section{CONCLUSION}

Results of this study indicated that there is a great possibility to use essential oils as biopreservatives in fermented milk. Indeed, both of essential oils tested showed inhibitory activity against microorganisms. It occurs that, essential oils could be used to control microbial contaminants of foods and could be able to growth of the Staphylococcus which have the minimal pH of growth around 4.2. Besides, for fermented milk preserved with essential oil, the efficiency of microbial flora decrease resulted from combination of acidity and essential oils. Indeed, for the milk added by essential oil of Pimenta Racemosa, it needed at least ten days to observe the disappearance of Staphylococcus when only five days were required for Xylopia aethiopica. These results showed a significant contribution of essential oils in inhibition of microbial flora. Indeed, according to Guylène et al. (1998), oil extracted from Pimenta racemosa were bacteriostatic and fungistatic. The same results had been reported for Xylopia aethiopica (Karioti et al., 2004). Moreover, antimicrobial activity of Xylopia aethiopica is more pronounced than that of Pimenta racemosa when compared the sample preserved with essential oils. This result could be explained by the fact that essential oil of Xylopia aethiopica contains more bacteriostatic substances than Pimenta racemosa' oil. Microbial activity of this oil was proved by several authors. Okigbo \& Nmeka (2005) showed the antifungal and antimicrobial power of essential oil extracted from $X y l o p i a$ aethiopica leaves. And its bactericidal activity was demonstrated by many authors (Alitonou, 2006; Noudogbessi et al., 2008; Yèhouénou et al., 2010a). Indeed, with their great potential to control pathogen in food materials, essential oils had been recognized as alternative in foods preservation by several authors (Burt, 2004; Dahouenon-Ahoussi et al., 2010). According to Kouninki et al. (2007), action of Xylopia aethiopica could be explained by its chemical composition. On the other hand, Samaddar et al. (2015) reported that the use of plant extracts and essential oils in consumer goods is expected to increase in the future because volatile oils can be considered as a natural alternative to synthetic food preservatives and could be used to enhance food safety and shelf life.

become useful tools for applications in foods preservation systems. The challenges for future are to determine the conditions, which avoid the loss of lactic bacteria; to preserve organoleptic characteristic of fermented milk after incorporation of essential oil; and preserve the effects of essential oils on food borne pathogens. 


\section{REFERENCES}

Abdenouri N, Idliman A, Kouhila M, 2008. Étude hygroscopique du lait en poudre. Revue des énergies renouvelables, Alger. 35-44.

Alitonou G, 2006. Huiles essentielles extraites de plantes aromatiques acclimatées au Bénin : étude chimique, évaluation biologique et applications potentielles. Thèse de Doctorat en cotutelle, Université d'Abomey-Calavi et Université Montpellier II. 283 pp

Alkoiret IT, Yari HM, Gbangboche AB, Lokossou R, 2011. Reproductive perfomance and milk production of girolando cows in the ranch of kpinnou, southwest of Benin Republic. Journal of Animal and Veterinary Advances 10 (19): 2588-2592.

Asekun OT. and Adeniyi BA, 2004. Antimicrobial and cytotoxic activities of the fruit essential oil of Xylopia aethiopica from Nigeria. Fitoterapia 75 (3-4): 368-370.

Bajpai KV, Dung NT, Kwon JO, Kang SC, 2008a. Analysis and the potential application of essential oil and leaf extracts of Silene Americana $\mathrm{L}$. to control food spoilage and foodborne pathogens, Journal of Food Technology 227: 1613-1620.

Bajpai VK, Rahman A, Kang SC, 2008b. Chemical composition and inhibitory parameters of essential oil and extracts of Nandina domestica. Thumb to control food-borne pathogenic and spoilage bacteria, International Journal of Food Microbiology 125: 117-122.

Burt S, 2004. Essential oils: their antibacterial properties and potential applications in foods. A review: International Journal of Food Microbiology 94: 223-253.

Dahouénon-Ahoussi E, Sessou P, Wotto DV, Yèhouénou $B$, Kinsoudé E, Kpatinvoh B, Soumanou M, Souhounhloué D, 2010. Mise au point d'une technologie de production d'une boisson locale Africa drink a base d'huiles essentielles de menthes verte et poivrée. Bulletin d'information de la Société Ouest Africaine de Chimie 7 : 3953.

Deans SG. and Ritchie G, 1987. Antibacterial properties of plant essential oils. International Journal of Food Microbiology 5: 165-180.

Dossou J, Hounzangbe-Adote S, Soule H, Chabi BI, 2006. Production and processing of fresh milk into Fulani cheese in Benin. Good Practice Guide. GRET-CAD/FSA. 33 pp.
Eymard S, 2003. Mise en évidence et suivi de l'oxydation des lipides au cours de la conservation et la transformation du Chinchard : choix des procédés. Thèse de doctorat Biochimie. École polytechnique de l'université de Nantes France.

Giordani R, Regli P, Kaloustian J, Mikail C, Abou L, Portugal $\mathrm{H}, 2005$. Antifungal effect of various essential oils against Candida albicans. Potential of antifungal action of amphotericin B by essential oil from Thymus vulgaris. In P. R.18 (12): 990-995.

Guylène SA, Jacqueline A, Paul B, Joëlle L, 1998. Antibacterial and antifungal activities of the essential oils of Pimenta racemosa var. racemosa P. Miller (J.W. Moore) (Myrtaceae). Journal of Essential Oil Research 10: 161-164.

Hammer KA, Carson CF, Ridley CV, 1999. Antimicrobial activity of essential oils and other plants extract. Journal of applied microbiology 86: 985-990.

Karioti A, Hadjipavlou-Litina D, Mensah MLK, Theophilus C, Skaltsa FH, 2004. Composition and Antioxidant Activity of the Essential Oils of Xylopia aethiopica (Dun) A. Rich. (Annonaceae) Leaves, Stem Bark, Root Bark, and Fresh and Dried Fruits, Growing in Ghana. J. Agric. Food Chem. 52 (26): 8094-8098

Kèkè $M$, Yèhouénou $B$, de Souza $C$, Sohounhloué $D$, 2009. Evaluation of hygiene and nutritional quality of peulh cheese treated by Sorghum vulgaris (L) and Pimenta racemosa (Miller) extracts. Scientific Study \& Research Chemistry \& Chemical Engineering, Biotechnology, Food Industry 10 (1): 29-46;

Kouninki $H$, Haubruge $E$, Noudjou $F E$, Lognay $G$, Malaisse $F$, Ngassoum MB, Goudou A, Mapongmetsem PM, Ngamo LS, Hance T, 2007. Toxicicty of some terpenoids of essential oils of Xylopia aethiopica from Cameroon against Sitophilus zeamais Motsch. Journal of Applied Entomology 131: 269-274.

Lambert RJW, Skandamis PN, Coote PJ, Nychas JEG, 2001. A study of the minimum inhibitory concentration and mode of action of oregano essential oil, thymol and carvacrol. Journal of Applied Microbiology 91: 453-462.

Mahaut $M$, Jeantet R, Brulé G, Schuck $P, 2000$. Les produits laitiers industriels. Tec. et Doc. Lavoisier, Paris. pp 52-55. 
Noudogbessi JP, Dansou K, Sohounhloué DCK, 2008. Composition Chimique et Propriétés Physicochimiques des Huiles Essentielles de Pimenta racemosa (Miller) et de Chromolaena odorata (L. Robinson) Acclimatées au Bénin. Journal de la Société Ouest-Africaine de Chimie : 026 : 11 19.

Noudogbessi JP, Natta AK, Avlessi F, Sohounhloué DCK, Figueredo G, Chalchat JC, 2011. Chemical composition of the essential oils extracted from two annonaceae required in Beninese pharmacopeia. Australian Journal of Basic and Applied Science 5 (2) : 34-40.

Ogodja JO, Hounsou-Vè G, Dehoux JP, 1991. Part I : Rôle et activité de la femme Peulh dans son ménage dans le sud Borgou au Bénin. Part II : Commercialisation du lait et des produits laitiers dans le sud Borgou en République du Bénin. Projet de Développement Pastoral Intégré dans le Borgou. Parakou Bénin. 20 pp.

Okigbo RN. and Nmeka IA, 2005. Control of yam tuber rot with leaf extracts of Xylopia aethiopica and Zingiber officinale. African Journal of Biotechnology 4 (8): 804-807.

Pillai LS. and Nair BR, 2013. Proximate composition, Mineral elements and Antinutritional factors in Cleome viscose L. and Cleome burmanni W. \& A. (Cleomaceae). Int. J. Pharm. Pharm. Sci. 5(1): 384-387.

Samaddar M, Ram C, Sen M, 2015. Assessment of storage stability of essential oil enriched flavoured milk. Indian J. Dairy Sci 68(4): 357363.

Rasooli I. and Mirmostafa SA, 2002. Antibacterial properties of Thymus pubescens and Thymus serpyllum essential oils. Fitoterapia 73(3): 244250.

Sacchetti G, Maietti S, Muzzoli M, Scaglianti M, Manfredini S, Radice M, Bruni R, 2005. Comparative evalution of 11 essential oils of different origin as functional antioxidants, antiradicals and antimicrobials in foods. Food Chemistry 91 (4): 621-632.

Smith-Palmer A, Stewart J, Fyfe L, 2001. The potential application of plant essential oils as natural food preservatives in soft cheese. Food Microbiology 18: 463-470.

Tepe B, Sokmen M, Akpulat HA, Daferera D, Polissiou M, Sokmen A, 2005. Antioxydative activity of the essential oils of thymus sipyleus and thymus sipyleus subsp. Sipyleus var. rosulans. Journal of Food Engineering 66 (4): 447-454.

Valero M. and Frances E, 2006. Synergistic bactericidal effect of carvacrol, cinnamaldehyde or thymol and refrigeration to inhibit Bacillus cereus in carrot broth. Food microbiology 23 (1) : 68-73.

Vierling $E, 2003$. Science des aliments. Aliments et boissons, Filières et produits. Doin éditeurs. Bordeaux cedex. p 25- 36.

Yèhouénou B, Noudogbessi JP, Sessou P, Avlessi F, Sohounhoué D, 2010a. Étude chimique et activités antimicrobiennes d'extraits volatils des feuilles et fruits de Xylopia aethiopica (Dunal) A. Rich. contre les pathogènes des denrées alimentaires. Journal de la Société OuestAfricaine de Chimie 029 : 19-27.

Yèhouénou $B$, Wotto $V$, Bankolé $H$, Sessou $P$, Noudogbessi JP, Sohounhloue D, 2010b. Chemical study and antimicrobial activities of volatile extracts from fresh leaves of Crassocephalum rubens (juss \& jack) s. moore against food-borne pathogens. Scientific Study \& Research : Chemistry \& Chemical Engineering, Biotechnology, Food Industry Vol 11 (3): 343-351. 